\title{
Intravenous Lipid Emulsion as an Adjuvant Therapy of Acute Antipsychotic Poisoning: A randomized Controlled Trial
}

\author{
Sara M. Basiouny, Mona S. Elgohary, Fatma M. Elgazzar, Heba I. Lashin ${ }^{1}$ \\ ${ }^{1}$ Department of Forensic Medicine and Clinical Toxicology, Faculty of Medicine - Tanta University, Tanta, Egypt.
}

\begin{abstract}
Background: Antipsychotics toxicity is one of the top five substances most frequently included in human poisoning. Various case reports documented successful use of intravenous lipid emulsion (ILE) in the management of acute antipsychotics poisoning. Aim: The aim of this study was to assess the efficacy and safety of ILE as adjuvant therapy for acute antipsychotic poisoning. Patients and methods: Forty patients presented with moderate to severe acute antipsychotic poisoning were randomly allocated into two equal groups. The control group was given the standard treatment only while the intervention group was given the standard treatment plus ILE infusion. For all patients, history, clinical examination, ECG, and laboratory investigations were done. The safety and efficacy outcomes were evaluated. Results: results revealed that the median Glasgow Coma Scale assessed at 6 and 12 hours after admission was significantly higher in the intervention group compared to the control group. Both corrected QT intervals measured 12 hours after admission and period of hospital stay were significantly shorter in the intervention group compared to the control group. During follow-up of the intervention group, there were no significant differences between serum triglycerides levels, liver enzymes and, platelet count measured at admission and 12 hours later. Conclusion: It was concluded that ILE was a safe and effective therapy for acute antipsychotic poisoning.
\end{abstract}

Received in original form: 4 June 2021 Accepted in a final form: 3 October 2021

Key words Acute poisoning; antipsychotic drugs; clinical trial; intravenous lipid emulsion; antidote

\section{Introduction}

A ntipsychotic drugs are a group of medications that are effective for the management of schizophrenia, bipolar mania, and depression (Krause et al., 2018). Dopamine $\left(\mathrm{D}_{2}\right)$ receptors are the primary target for antipsychotic drugs (Wang et al., 2018). The efficacy of antipsychotic drugs correlates strongly with their capacities for blocking $\mathrm{D}_{2}$ receptors in the basal ganglia, hypothalamus, medulla oblongata, chemotactic trigger zone in addition to mesocortical, and mesolimbic pathways of the brain (Ayano, 2016).

According to the 2018 annual report of the American Association of Poison Control Centres (AAPCC), antipsychotics toxicity is one of the top five substances most frequently included in human poisoning (Gummin et al., 2019). Additionally, a recent study in Egypt has identified antipsychotic drugs as the second most common (20\%) central nervous system pharmaceutical drugs' poisoning among medicinal poisonings presented to the emergency department of the National Poisoning Center, Cairo University (Rasheed et al., 2020).

Antipsychotic drugs are classified into; typical antipsychotics (like chlorpromazine, haloperidol, and thiothixene) and atypical antipsychotics (like clozapine, quetiapine, and olanzapine) (Adem et al., 2019). Typical antipsychotics have higher rates of neurologic side effects than atypical ones. These include extrapyramidal syndromes such as acute dystonia, pseudoparkinsonism, and akathisia (McPhie and Kirchhof, 2020). Therefore, the atypical antipsychotic drugs have largely replaced the typical agents for their enhanced efficacy and safety (Adeosun, 2016).

The most common finding following antipsychotics overdose is the central nervous system (CNS) depression. It ranges from drowsiness, confusion and, slurred speech in mild intoxication to deep coma in severely intoxicated patients (Stassinos and Klein-Schwartz, 2017). Furthermore, cardiovascular manifestations have been frequently reported following antipsychotics toxicity. They include sinus tachycardia, hypotension, in addition to electrocardiographic (ECG) abnormalities such as prolongation of corrected QT (QTc) interval (Borg et al., 2016; Zainuddin and Zaini, 2018).

In the absence of specific antidote, treatment of acute antipsychotics overdose depends mainly on supportive treatment determined by the clinical condition of the patient. It includes care of the airway and breathing support, cardiac monitoring, intravenous (IV) fluids, in addition to gastrointestinal decontamination to prevent further absorption (Barman, et al., 2018). 
Intravenous lipid emulsion (ILE) is originally developed to supply patients requiring parenteral nutrition with essential fatty acids (ok et al., 2018). Many different ILE products vary in their formulations. Smoflipid® is a common commercial preparation, which is composed of $30 \%$ medium-chain triglycerides, $30 \%$ soybean oil, $25 \%$ olive oil, and $15 \%$ fish oil (Casson, et al., 2020).

Recently, the potential role of ILE as an antidote for drug poisoning has been recognized (Tampakis et al., 2020). Successful usage of ILE in the treatment of acute lipophilic drugs poisoning including b-blockers, calcium channel blockers, and a variety of antipsychotic drugs has been reported in animal researches in addition to many case reports (Finn et al., 2009; Purg et al., 2016; Karakilic et al., 2017; Yousefsani et al., 2019).

Despite the increased concern for utilizing ILE therapy in the treatment of lipophilic drugs toxicity including antipsychotics, there is a paucity of data, with low-quality evidence depending mainly on case reports with no reported randomized controlled clinical trial (RCT). Therefore, this study aimed to evaluate the potential efficacy and safety of ILE as adjuvant therapy for acute antipsychotics poisoning.

\section{Patients and Methods}

Study design, settings, and ethical considerations

After approval of the research ethics committee, Faculty of Medicine, Tanta University, Egypt (approval number: 32944/02/19), this controlled randomized phase II parallel-group, single-blinded clinical trial was conducted in Tanta University Poison Control Center (TUPCC), Tanta University Emergency Hospital, Egypt from March 2019 to February 2020. Each patient or his/her legal guardians (if the patient was unable to participate in the consent process) received detailed information about the study to obtain written informed consent. A code number for each patient was made to preserve the confidentiality of data that were analyzed anonymously.

\section{Patients' selection criteria}

Inclusion criteria: Male or female patients of any age with symptoms of moderate to severe acute antipsychotic drug poisoning. At admission, the severity of CVS, CNS, and respiratory symptoms, as well as any metabolic abnormalities, were graded using the standardized poisoning severity score (PSS) (Persson et al., 1998).

Exclusion criteria: Asymptomatic and mild cases, patients reported co-ingestion of other substances along with antipsychotic drugs, presented more than 12 hours after antipsychotics ingestion, or received any treatment before admission to the TUPCC. Patients suffered from any forms of ECG changes especially prolonged QTc intervals irrelevant to antipsychotic drug toxicity. Women who are pregnant or lactating, patients with serious medical conditions (e.g. cardiovascular disease, hepatic or renal failure), with a known history of hyperlipidemia, or patients in whom serum triglyceride levels exceeded $400 \mathrm{mg} / \mathrm{dL}$ on admission were all excluded (Raman et al., 2017).
Acute antipsychotic poisoning was diagnosed using a history obtained from the patients or their relatives, the compound's identification using the container brought by the patient's family, and the detection of most common suggestive clinical manifestations of acute antipsychotic drugs toxicity: sedation, extrapyramidal symptoms (including acute dystonia, pseudoparkinsonism, and akathisia), hypotension and prolonged QT interval (Thanacoody, 2020). Additionally, measurement of the serum drug concentration on admission by using high-performance liquid chromatography (HPLC) was only available for clozapine drugs.

\section{Methods}

Forty patients were randomly assigned into two equal groups (control and intervention groups, 20 patients each, allocation ratio: 1:1) by using a random number generator website. The sequentially numbered, sealed opaque envelopes method stated by Doig and Simpson (2005) to hide the distribution sequence was used.

Patients allocated in the control group received the conventional treatment of acute antipsychotic toxicity according to the TUPCC protocol that based on the international guidelines i) Gastrointestinal decontamination either by gastric lavage if the patient presented early within one hour of toxic ingestion or activated charcoal if the patient presented later (MazerAmirshahi et al., 2019). ii) The standard supportive care comprises, maintaining patent airways, oxygen administration, breathing support when necessary, treatment of hypotension by intravenous fluids, continuous cardiac monitoring until resolving all symptoms as well as ECG abnormalities, treatment of prolonged QTc interval with magnesium sulfate if there is evidence of dysrhythmia such as torsades de pointes and treatment of QRS prolongation with sodium bicarbonate. Furthermore, acute dystonia was recorded in some cases and was treated with benzodiazepines (Minns and Clark, 2012; Gibiino et al., 2015; MazerAmirshahi et al., 2019).

Patients allocated in the intervention group received the same lines of treatment as in the control group plus ILE (Smoflipid® 20\%; a mixture of soybean oil, medium-chain triglycerides, olive, and fish oil). It was administrated as an initial bolus dose: 1.5 $\mathrm{mL} / \mathrm{kg}$ over 1 to 2 minutes followed by a maintenance dose $(6 \mathrm{~mL} / \mathrm{kg})$ IV infusion over one hour. After the infusion was completed the patient was continuously reassessed for the possible requirement of an additional bolus dose if necessary (Purg et al., 2016). For pediatric patients, the regimen of treatment by ILE was similar to the adult recommendations (Anez-Bustillos et al., 2016). Patients were closely monitored during the hospital stay to detect any adverse effects.

For all patients, demographic, toxicological data, and time elapsed between the toxic exposure and hospital admission were collected. Additionally, a full clinical examination including monitoring of vital signs and assessment of the level of consciousness by GCS was done. For children below 2 years, the pediatric GCS according to Hoffmann et al. (2016) was applied. 
A twelve-leads ECG was recorded on admission and repeated when an abnormality was observed on cardiac monitoring as well as 12 hours after admission. Electrocardiograms were analyzed for rate, rhythm, axis, and the presence of dysrhythmias or any conduction defects. Corrected QT interval (QTc) was measured according to Bazett's formula: QTc = $\mathrm{QT} / \sqrt{\mathrm{RR}}$ (Su et al., 2017). A prolonged QTc is diagnosed if more than $0.45 \mathrm{sec}$ in males and more than $0.47 \mathrm{sec}$ in females (Corponi et al., 2019).

According to Nelson et al. (2011), the normal ranges of systolic and diastolic blood pressure $(\mathrm{mmHg})$, pulse (beat/min), respiratory rate (cycle/min) and temperature $\left({ }^{\circ} \mathrm{C}\right)$ in adults are 90-130/60-90, 60$100,16-24$ and 35-38 respectively. Regarding vital signs in children, the normal ranges of blood pressure, pulse, and respiratory rate were determined according to standardized blood pressure, pulse, and respiratory rate tables (Hartman and Cheifetz, 2011). Moreover, the axillary temperature should be considered as fever when they are more than $37.0^{\circ} \mathrm{C}$ (Oguz et al., 2018).

Blood samples were obtained from each patient immediately on admission and before giving any medications, for measuring serum clozapine concentrations and baseline routine laboratory investigations; these included levels of serum triglycerides, serum sodium and potassium, blood urea and serum creatinine, serum glutamic pyruvic transaminase (SGPT), serum glutamic oxaloacetic transaminase (SGOT), complete blood count (CBC) and random blood sugar, in addition to arterial blood gases.

Measurement of serum clozapine levels was done by Young $\operatorname{Lin}^{\odot}$ (YL-9100) high-performance liquid chromatography (HPLC) system at Ain Shams Poison Control Center, Cairo, Egypt. Twelve hours after admission, another blood sample was withdrawn for reevaluation of serum triglyceride levels (reference range: $35-160 \mathrm{mg} / \mathrm{dL}$ ) (Nagamine, 2008), SGPT and SGOT, and platelet count as recommended by Spray (2016).

All patients were prospectively monitored for consciousness levels, vital signs, ECG, QTc interval, and the development of any complications or idiosyncratic reactions until discharge from the hospital.

\section{Outcome measures}

Regarding safety outcome measures, lipid emulsion safety assessment was based on evaluation of serum triglycerides levels, liver enzymes, and platelet count 12 hours after admission besides the continuous clinical monitoring of the patients in the intervention group for any adverse effects. Furthermore, the efficacy outcome measures included the total inhospital mortality, improvement in consciousness levels assessed by GCS, improvement of the vital signs, ECG changes, and QTc interval, need for intubation, and/or ICU admission in addition to the duration of hospital stay.

Statistical Analysis
All data were tabulated and statistically analyzed by utilizing Statistical Package for the Social Sciences (SPSS) program, version 22. Continuous variables were tested for normality by the Shapiro Wilk test. Normally distributed data were displayed as mean \pm SD. The differences between the studied groups were verified using Independent T-test. Otherwise, data that showed abnormal distribution were presented as the median and interquartile range (25th - 75th percentile) and were compared by using the Mann-Whitney U test. Categorical variables were displayed as frequencies and percentages. Additionally, the association between variables was verified using $\mathrm{X}^{2}$ tests (Pearson's ChiSquare for independence or Fisher's Exact Tests as appropriate). Moreover, a Paired T-test was applied to compare serum triglyceride levels, platelet count, and liver enzymes measured on admission and 12 hours later during follow-up of the intervention group. Spearman's Rank correlation was done to assess the association between the severity of poisoning and the serum clozapine level. Repeated measures ANOVA was used to compare the vital signs detected on admission, at 6 and 12 hours within each of the control and intervention groups. A p-value of $<0.05$ was considered statistically significant.

\section{Results}

No significant difference was found between the studied groups regarding the patient's demographics or toxicological characteristics (Table 1). Both groups were homogeneous regarding age and gender. Clozapine poisoning was the most frequently detected antipsychotic poisoning $(65 \%)$, followed by chlorpromazine (15\%), risperidone (12.5\%), haloperidol (5\%), and finally olanzapine (2.5\%). Regarding the route of exposure, all patients reported oral ingestion of the antipsychotic drugs. The alleged manner of poisoning in the studied patients was either accidental $(52.5 \%)$ or suicidal $(47.5 \%)$. There were only 5 patients $(12.5 \%)$ with severe antipsychotic poisoning according to PSS. The time interval between toxic ingestion of the drug and admission to the hospital had a median of four hours in the control group, while its median was five hours in the intervention group. This difference was statistically insignificant as illustrated in the table (1).

Table (2) showed that the vital signs, clinical and electrocardiographic findings that were obtained on admission were homogeneously distributed among the studied groups with no significant difference. The mean GCS assessed on admission was $9 \pm 2.7$ in the control group in comparison to $10.1 \pm 2.2$ in the intervention group with no significant difference. Acute dystonia was the only finding in both groups with no significant differences. However, signs of aspiration pneumonia (respiratory distress and localized diminished air entry) were observed in $15 \%$ of the control group opposite to $10 \%$ of the intervention group with no significant difference. Regarding electrocardiographic findings, most of the patients in the control and intervention groups showed sinus tachycardia associated with prolonged QTc interval (55\% and 70\%, respectively) (Figures 1,2). 
Furthermore, routine laboratory investigations were almost the same with no significant difference between both groups as illustrated in the table (3).

Based on Mann Whitney test, no significant difference was found between the studied groups as regards serum clozapine levels drawn on admission ( $\mathrm{z}_{\mathrm{mw}}$ : 0.616, p-value: 0.545). Spearman's rank correlation between the severity of the intoxication and the obtained serum clozapine levels on admission revealed a non-significant association (correlation coefficient $\left.\mathrm{r}_{\mathrm{s}}=-0.145, \quad P=0.481\right)$. Concerning the amount of the received ILE, no patients required an additional bolus dose administration and according to their weight, the total amount of obtained ILE ranged from 90 to $850 \mathrm{ml}$ with a median amount of $335 \mathrm{ml}$ (IQR=142.5-533.75 ml).

Regarding both safety and efficacy outcomes of the studied groups, all patients in the studied groups were completely improved with no recorded mortality in both groups. Table (4) shows that the medians of GCS evaluated at 6 and 12 hours later after admission were a significantly higher in the intervention group than in the control group ( 15 versus 10 after 6 hours and 15 versus 14 after 12 hours, respectively). Assessment of ECG findings recorded at 12 hours after hospital admission showed significantly higher normal ECG percentage in the intervention group $(80 \%)$ than in the control group (40\%). Additionally, the percentage of prolonged QTc interval was significantly higher in the control group compared to the intervention group (55\% versus $20 \%$ respectively). The QTc interval was assessed 12 hours later after admission. Its median value was significantly higher in the control group compared to the intervention group (0.48 sec versus $0.44 \mathrm{sec}$, respectively).

Only one patient $(5 \%)$ in the intervention group needed intubation and ICU admission compared to three patients $(15 \%)$ in the control group. No significant difference regarding the need for endotracheal intubation and/or ICU admission between both groups was shown. Moreover, patients in the intervention group revealed significantly shorter durations of hospital stay compared to those in the control group (18 and 42 hours, respectively) (Table 4).

Moreover, a comparison of the mean pulse, systolic \& diastolic blood pressures, respiratory rate, and temperature that were recorded on admission, at 6 hours and 12 hours within each of the control group and the intervention group revealed non-significant differences (Figure 3).

Clinical monitoring of patients in the intervention group revealed no adverse effects. Table (5) shows a comparison of serum triglycerides levels, liver enzymes, and platelet count measured on hospital admission and 12 hours later during the follow-up of the intervention group to assess the safety of ILE. No significant differences between the means of these parameters were shown. 
Table (1): Percentage of baseline demographic and toxicological characteristics of the studied groups.

\begin{tabular}{|c|c|c|c|c|c|c|}
\hline \multirow{2}{*}{\multicolumn{2}{|c|}{ Variables }} & \multicolumn{2}{|c|}{ Groups } & \multirow{3}{*}{$\begin{array}{c}\begin{array}{c}\text { Total } \\
(\mathrm{n}=\mathbf{4 0})\end{array} \\
1-37\end{array}$} & \multirow{2}{*}{$\begin{array}{c}\text { Test } \\
\text { statistic }\end{array}$} & \multirow[b]{2}{*}{$\begin{array}{c}P \\
\text { value }\end{array}$} \\
\hline & & \multirow{2}{*}{$\begin{array}{c}\begin{array}{c}\text { Control } \\
\text { group } \\
(\mathbf{n}=\mathbf{2 0})\end{array} \\
1.5-37 \\
\end{array}$} & \multirow{2}{*}{$\begin{array}{c}\begin{array}{c}\text { Intervention } \\
\text { group } \\
(\mathbf{n}=\mathbf{2 0})\end{array} \\
1-29\end{array}$} & & & \\
\hline \multirow{3}{*}{$\begin{array}{c}\text { Age } \\
\text { (years) }\end{array}$} & Min.-max. & & & & \multirow{3}{*}{$\begin{array}{c}\mathrm{Z}_{\mathrm{mw}} \\
0.529\end{array}$} & \multirow{3}{*}{0.602} \\
\hline & Median (IQR) & $\begin{array}{c}13.5 \\
(5-21.5)\end{array}$ & $\begin{array}{c}10 \\
(4-18.5)\end{array}$ & $\begin{array}{c}10 \\
(4-21)\end{array}$ & & \\
\hline & Mean rank & 21.48 & 19.52 & & & \\
\hline \multirow{2}{*}{ Gender } & Female, n (\%) & $9(45)$ & $14(70)$ & $23(57.5)$ & \multirow{2}{*}{$\begin{array}{c}X^{2} \\
2.588 \\
\end{array}$} & \multirow{2}{*}{0.110} \\
\hline & Male, n (\%) & $11(55)$ & $6(30)$ & $17(42.5)$ & & \\
\hline \multirow{5}{*}{$\begin{array}{l}\text { Generic drug } \\
\text { name }\end{array}$} & Clozapine, n (\%) & $13(65)$ & $13(65)$ & $26(65)$ & \multirow{5}{*}{$\begin{array}{l}X^{2} \text { exact } \\
1.531\end{array}$} & \multirow{5}{*}{0.999} \\
\hline & Chlorpromazine, n (\%) & $3(15)$ & $3(15)$ & $6(15)$ & & \\
\hline & Risperidone, n (\%) & $2(10)$ & $3(15)$ & $5(12.5)$ & & \\
\hline & Haloperidol, n (\%) & $1(5)$ & $1(5)$ & $2(5)$ & & \\
\hline & Olanzapine, n (\%) & $1(5)$ & $0(0)$ & $1(2.5)$ & & \\
\hline \multirow{2}{*}{$\begin{array}{l}\text { Alleged mode of } \\
\text { poisoning }\end{array}$} & Accidental, n (\%) & $10(50)$ & 11(55) & $21(52.5)$ & \multirow{2}{*}{$\begin{array}{c}X^{2} \\
0.10\end{array}$} & \multirow{2}{*}{0.752} \\
\hline & Suicidal, n (\%) & $10(50)$ & $9(45)$ & $19(47.5)$ & & \\
\hline \multirow{2}{*}{$\begin{array}{c}\text { Severity } \\
\text { according to } \\
\text { PSS }\end{array}$} & Moderate, n (\%) & $17(85)$ & $18(90)$ & $35(87.5)$ & \multirow{2}{*}{$\begin{array}{c}X^{2} \\
0.229\end{array}$} & \multirow{2}{*}{0.633} \\
\hline & Severe, n (\%) & $3(15)$ & $2(10)$ & $5(12.5)$ & & \\
\hline \multirow{3}{*}{$\begin{array}{l}\text { Alleged dose } \\
\qquad(\mathrm{mg})\end{array}$} & Min.-max. & $10-500$ & $5-500$ & $5-500$ & \multirow{3}{*}{$\begin{array}{c}\mathrm{Z}_{\mathrm{mw}} \\
0.908\end{array}$} & \multirow{3}{*}{0.379} \\
\hline & Median (IQR) & $\begin{array}{c}75 \\
(25-100)\end{array}$ & $\begin{array}{c}125 \\
(25-200)\end{array}$ & $\begin{array}{c}100 \\
(25-162.5)\end{array}$ & & \\
\hline & Mean rank & 16.82 & 20 & & & \\
\hline \multirow{3}{*}{$\begin{array}{l}\text { Time interval } \\
\text { between toxic } \\
\text { exposure and } \\
\text { hospital } \\
\text { admission (h) }\end{array}$} & Min.-max. & $1-10$ & $2-22$ & $1-22$ & \multirow{3}{*}{$\begin{array}{c}Z_{\mathrm{mw}} \\
0.462\end{array}$} & \multirow{3}{*}{0.662} \\
\hline & Median (IQR) & $4(3.5-6)$ & $5(3-6)$ & $4(3-6)$ & & \\
\hline & Mean rank & 18.25 & 19.88 & & & \\
\hline
\end{tabular}

n: number; IQR: Interquartile rang; Min.-max.: Minimum-Maximum; PSS: poison severity score; mg: milligram; $h$ : hour; $\chi 2$ : Chi square test; $Z_{m w}$ : Mann-Whitney test. 
Table (2): Percentage of baseline vital data and clinical findings of the studied groups.

\begin{tabular}{|c|c|c|c|c|c|c|}
\hline \multirow{2}{*}{\multicolumn{2}{|c|}{ Variables }} & \multicolumn{2}{|c|}{ Groups } & \multirow[b]{2}{*}{$\begin{array}{c}\text { Total } \\
(n=40)\end{array}$} & \multirow[b]{2}{*}{$\begin{array}{c}\text { Test } \\
\text { statistic }\end{array}$} & \multirow[b]{2}{*}{$\begin{array}{c}P \\
\text { value }\end{array}$} \\
\hline & & Control & Intervention & & & \\
\hline \multirow{2}{*}{ GCS } & Min.-max. & $4-14$ & $6-13$ & $4-14$ & \multirow{2}{*}{$\begin{array}{c}t \\
1.489\end{array}$} & \multirow{2}{*}{0.145} \\
\hline & Mean \pm SD & $9 \pm 2.7$ & $10.1 \pm 2.2$ & $9.5 \pm 2.5$ & & \\
\hline Pulse rate (beats/min) & Tachycardia, n (\%) & $16(80)$ & $17(85)$ & $33(82.5)$ & $X^{2} 0.173$ & 0.677 \\
\hline $\begin{array}{l}\text { Blood pressure } \\
(\mathrm{mmHg})\end{array}$ & Hypotension, n (\%) & $7(35)$ & $9(45)$ & $16(40)$ & $X^{2} 0.417$ & 0.519 \\
\hline $\begin{array}{c}\text { Respiratory rate } \\
\text { (breaths/min) }\end{array}$ & Tachypnea, n (\%) & $4(20)$ & $3(15)$ & $7(17.5)$ & $X^{2} 0.173$ & 0.677 \\
\hline Temperature $\left({ }^{\circ} \mathbf{C}\right)$ & Fever, n (\%) & $3(15)$ & $5(25)$ & $8(20)$ & $X^{2} 0.625$ & 0.429 \\
\hline \multirow{2}{*}{ Pupil } & Constricted, n (\%) & $15(75)$ & $17(85)$ & $32(80)$ & \multirow{2}{*}{$X^{2} 0.156$} & \multirow{2}{*}{0.347} \\
\hline & RRR, n (\%) & $5(25)$ & $3(15)$ & $8(20)$ & & \\
\hline $\begin{array}{l}\text { Extrapyramidal } \\
\text { manifestations }\end{array}$ & Acute dystonia, n (\%) & $1(5)$ & $2(10)$ & $3(7.5)$ & $X^{2} 0.00$ & $>0.999$ \\
\hline Chest & Aspiration pneumonia, n (\%) & $3(15)$ & $2(10)$ & $5(12.5)$ & $X^{2} 0.00$ & 1.0 \\
\hline \multirow{4}{*}{ ECG interpretation } & Normal, n (\%) & $4(20)$ & $1(5)$ & $5(12.5)$ & \multirow{4}{*}{$\begin{array}{c}X^{2} \\
4.384\end{array}$} & \multirow{4}{*}{0.336} \\
\hline & Prolonged $\mathrm{QT}_{\mathrm{c}}, \mathrm{n}(\%)$ & $0(0)$ & $1(5)$ & $1(2.5)$ & & \\
\hline & Sinus tachycardia, n (\%) & $5(25)$ & $4(20)$ & $9(22.5)$ & & \\
\hline & $\begin{array}{c}\text { Sinus tachycardia+ } \\
\text { prolonged } \mathrm{QT}_{\mathrm{c}, \mathrm{n}}, \mathrm{n}(\%)\end{array}$ & $11(55)$ & $14(70)$ & $25(62.5)$ & & \\
\hline \multirow{2}{*}{$\begin{array}{c}\text { Corrected QT interval } \\
(\mathrm{sec})\end{array}$} & Min.-max. & $0.36-0.63$ & $0.37-0.60$ & $0.36-0.63$ & \multirow{2}{*}{$\begin{array}{c}t \\
0.050\end{array}$} & \multirow{2}{*}{0.960} \\
\hline & Mean \pm SD & $0.48 \pm 0.07$ & $0.48 \pm 0.06$ & $0.48 \pm 0.06$ & & \\
\hline
\end{tabular}

n: number; SD: Standard deviation; Min.-max.: Minimum-Maximum; GCS: Glasgow coma score; RRR: rounded regular reactive; ECG: Electrocardiogram; QTc: Corrected QT; sec: second; $t$ : Independent T test; $\chi 2$ : Chi square test.

Table (3): Percentage of baseline laboratory investigations obtained on admission in the studied groups.

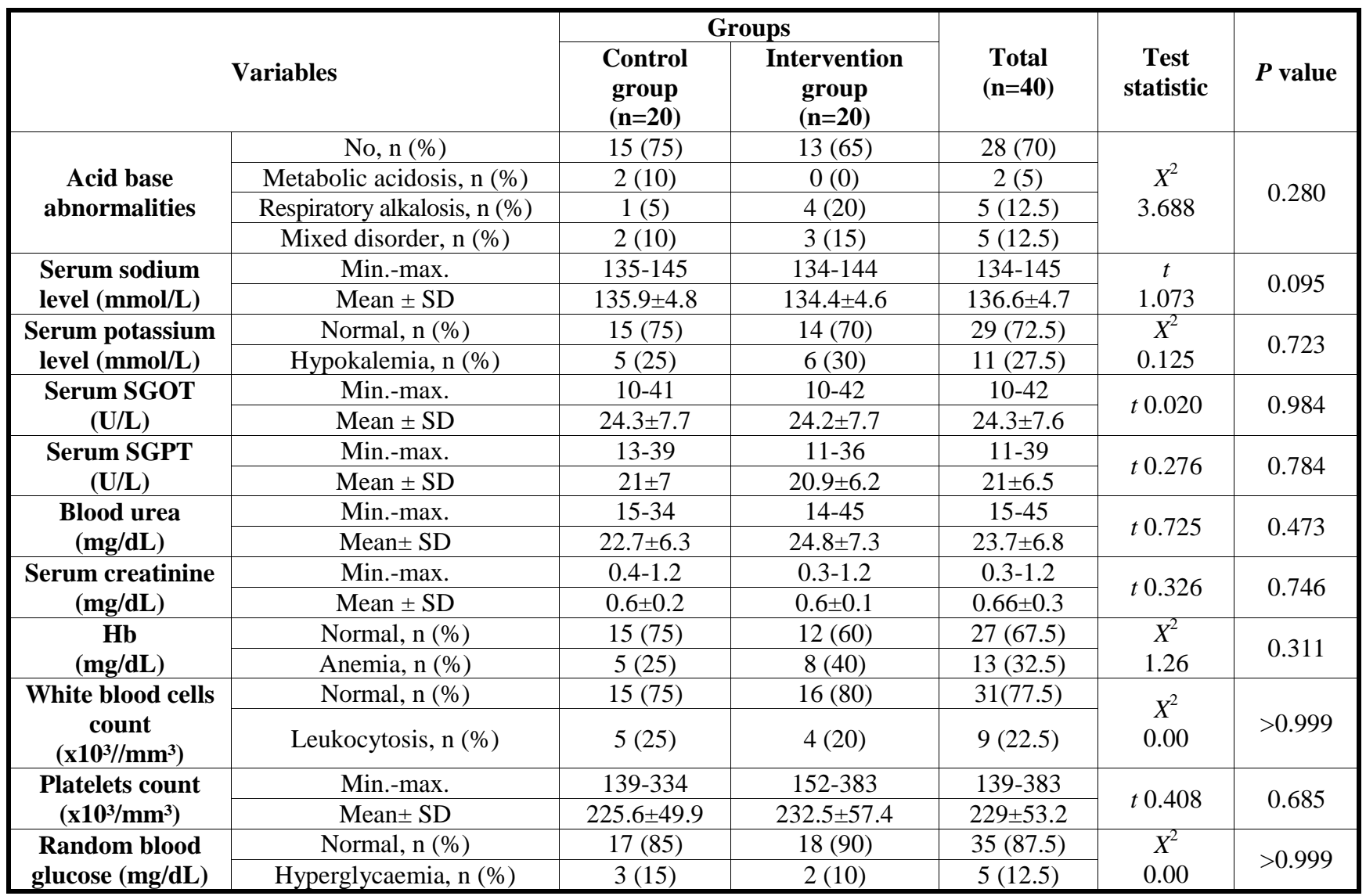

n: number; SD: Standard deviation; Min.-max.: Minimum-Maximum; mg/dL: milligrams per decilitre; U/L: Unit per Litre; SGPT: serum glutamic pyruvic transaminase; SGOT: serum glutamic oxaloacetic transaminase; Hb: haemoglobin; $t$ : Independent T test; $\chi 2$ : Chi square test. 
Table (4): Mann-Whitney $U$ test and Chi square test statistical analysis of comparison of outcomes of the studied groups.

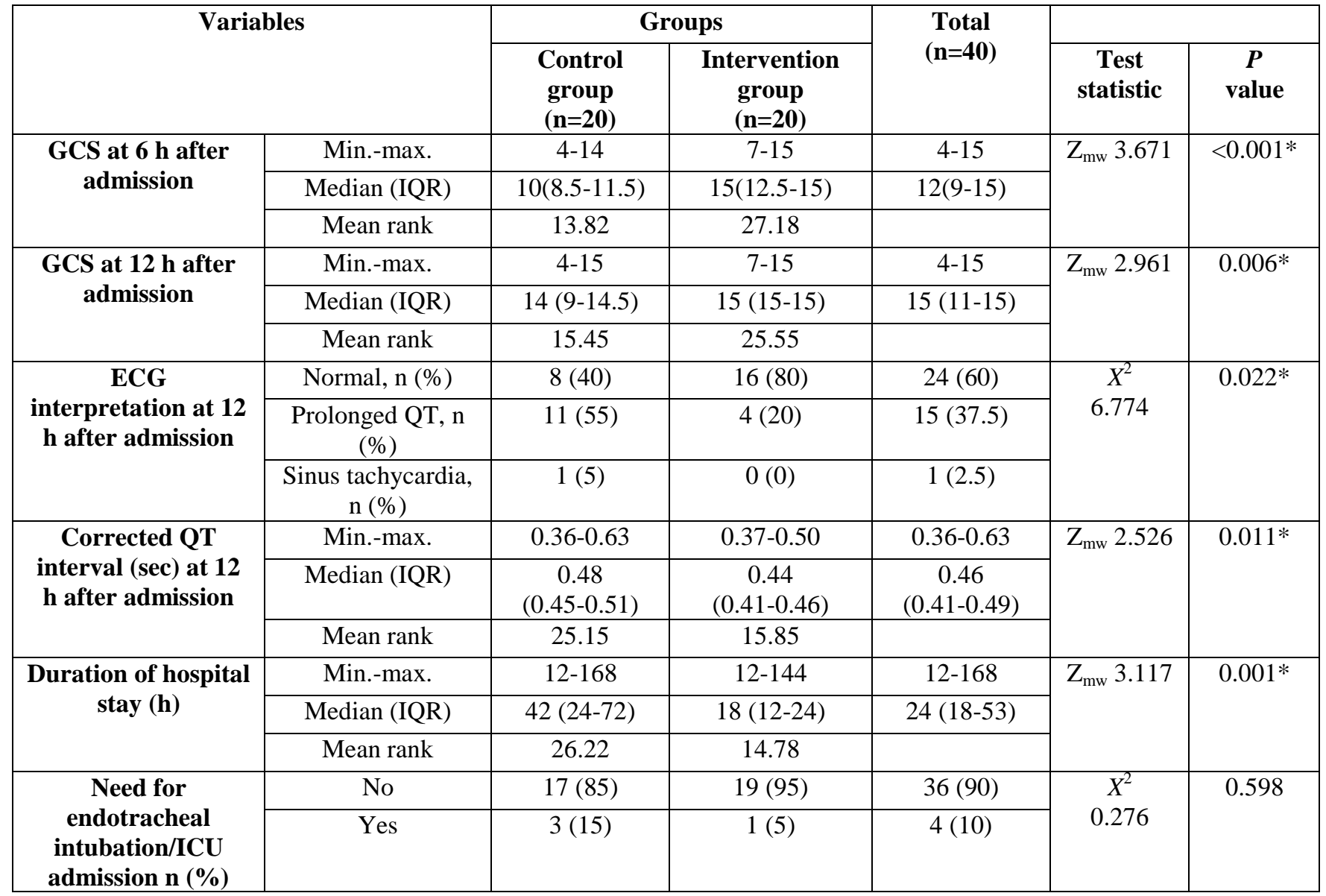

*significant at $p<0.05$; $n$ : number; GCS: Glasgow coma score; ECG: Electrocardiogram; ICU: intensive care unit; h: hour; Min.-max.: Minimum-Maximum; IQR: Interquartile range; $Z_{m w}$ : Mann-Whitney test; $\chi 2$ : Chi square test.

Table (5): Paired $\mathbf{t}$ test statistical analysis of comparison of serum triglyceride levels, platelets count, and liver enzymes obtained on admission and 12 hours later in the intervention group.

\begin{tabular}{|c|c|c|c|c|c|}
\hline \multirow{2}{*}{\multicolumn{2}{|c|}{ Variables }} & \multicolumn{2}{|c|}{$\begin{array}{c}\text { Intervention group } \\
(\mathrm{n}=\mathbf{2 0})\end{array}$} & \multicolumn{2}{|c|}{ Paired T test } \\
\hline & & On admission & After 12 h & $t$ & $P$ value \\
\hline \multirow{2}{*}{$\begin{array}{c}\text { Serum triglycerides level } \\
(\mathrm{mg} / \mathrm{dL})\end{array}$} & Min.-max. & $40-160$ & $40-167$ & \multirow{2}{*}{1.907} & \multirow{2}{*}{0.072} \\
\hline & Mean \pm SD & $87.2 \pm 34.6$ & $100.2 \pm 37.3$ & & \\
\hline \multirow{2}{*}{ Platelets count $\left(\mathrm{x10}^{3} / \mathrm{mm}^{3}\right)$} & Min.-max. & $152-383$ & $150-380$ & \multirow{2}{*}{1.308} & \multirow{2}{*}{0.199} \\
\hline & Mean \pm SD & $232.5 \pm 57.4$ & $228.2 \pm 53.2$ & & \\
\hline \multirow{2}{*}{$\begin{array}{l}\text { Serum SGOT } \\
(\mathrm{U} / \mathrm{L})\end{array}$} & Min.-max. & $10-42$ & $12-45$ & \multirow{2}{*}{0.497} & \multirow{2}{*}{0.622} \\
\hline & Mean \pm SD & $24.2 \pm 7.7$ & $24.7 \pm 8.2$ & & \\
\hline \multirow{2}{*}{$\begin{array}{c}\text { Serum SGPT } \\
(\mathrm{U} / \mathrm{L})\end{array}$} & Min.-max. & $11-36$ & $10-40$ & \multirow{2}{*}{1.109} & \multirow{2}{*}{0.274} \\
\hline & Mean \pm SD & $20.9 \pm 6.2$ & $22 \pm 6.9$ & & \\
\hline
\end{tabular}

n: number; SD: Standard deviation; Min.-max.: Minimum-Maximum; mg/dL: milligrams per decilitre; U/L: Unit per Litre; SGPT: serum glutamic pyruvic transaminase; SGOT: serum glutamic oxaloacetic transaminase; $t$ : Independent $T$ test. 


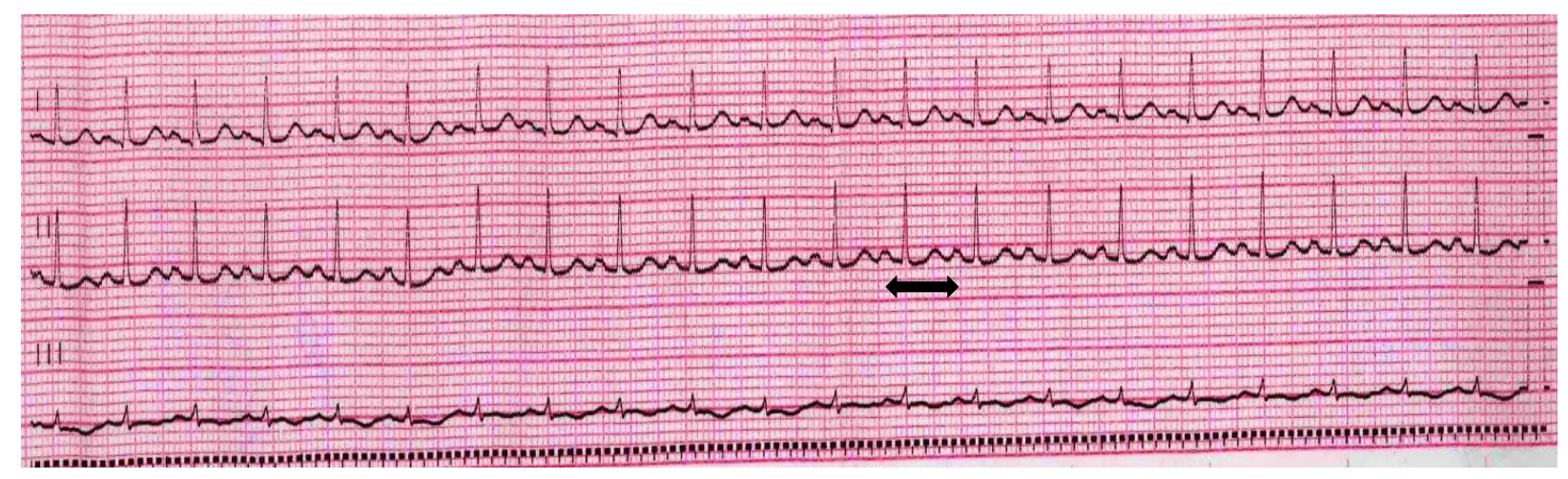

Figure (1): A strip of ECG from a female patient aged 17 years with acute antipsychotic poisoning (clozapine) shows sinus tachycardia with prolonged QT interval (QTc: $549.91 \mathrm{msec}$ ) (black arrow).

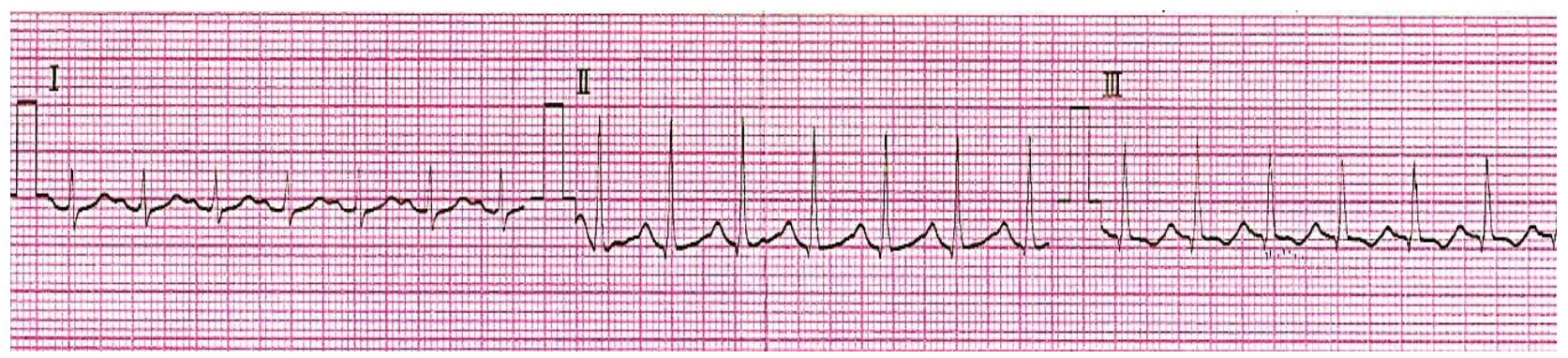

Figure (2): A strip of ECG from a female patient aged 19 years with acute antipsychotic poisoning (olanzapine) showed sinus tachycardia with prolonged QT interval (QTc: 452.5 msec). 

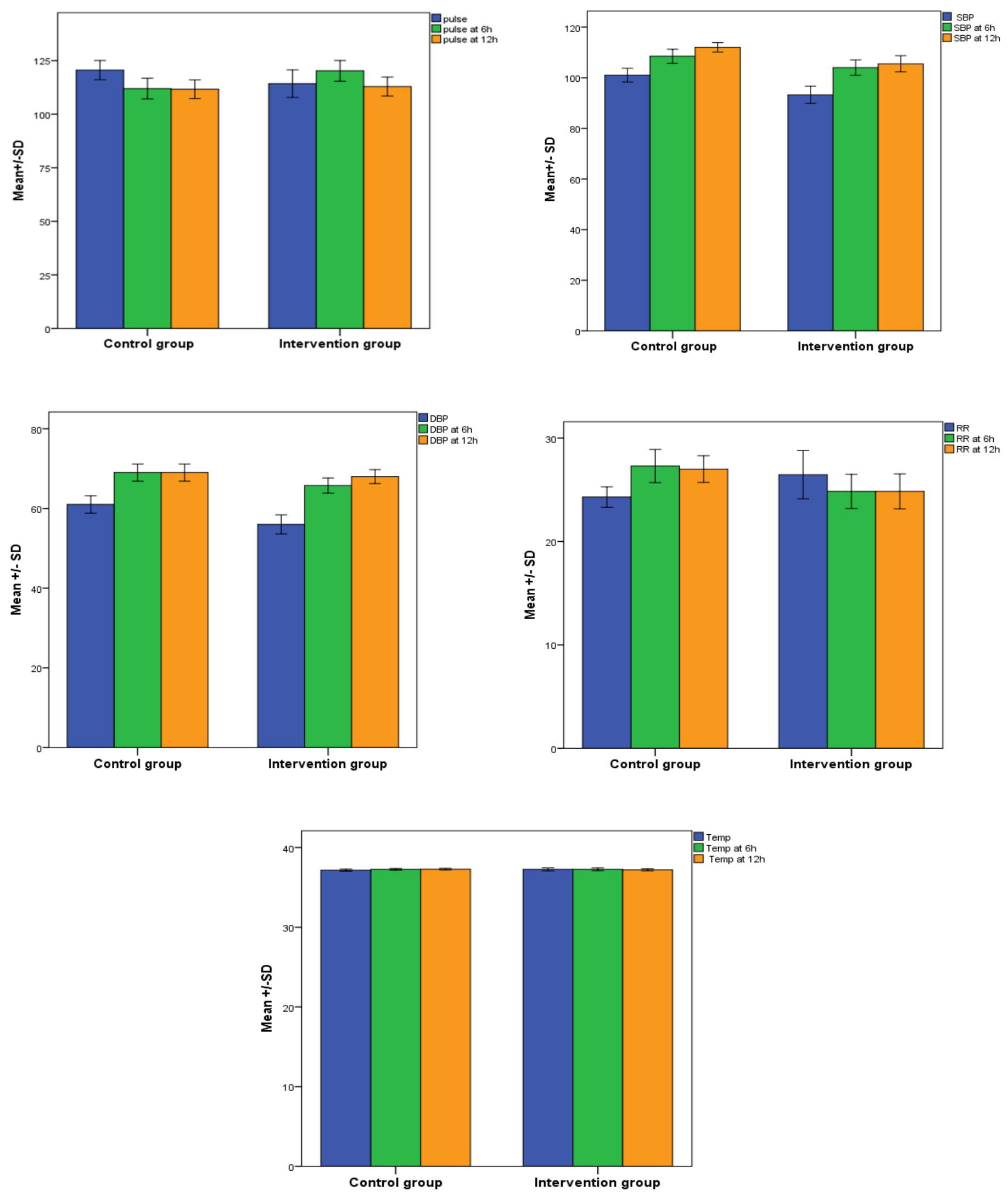

Figure (3): Comparison between the means of vital signs (pulse, systolic \& diastolic blood pressure, respiratory rate, temperature) on admission, at 6 and 12 hours within each the control and intervention groups. 


\section{Discussion}

Globally, a rapid increase in the incidence of acute antipsychotic drugs poisoning is observed. They represent one-fifth of the number of acute poisonings among psychiatric patients (Zhang et al., 2020). The increased incidence of acute antipsychotics poisoning and its high morbidity are real challenges for health professionals. Unfortunately, there is no specific antidote for antipsychotics overdose and its management is mainly supportive and symptomatic (Thanacoody, 2020). Hence, evaluation of new treatment modalities is necessary to decrease the rate of morbidity and/or mortality.

There is growing concern about the use of ILE therapy to treat lipophilic drug toxicity. Consequently, for assessing the efficacy, safety, indications, and the best regimen for ILE therapy, there is a need for randomized controlled clinical trials (Gosselin et al., 2016). Therefore, this study aimed to evaluate the potential efficacy and safety of ILE as adjuvant therapy for acute antipsychotics poisoning.

The present study was conducted on 40 patients who met the eligibility criteria and presented with manifestations of moderate to severe acute antipsychotics toxicity. By using a random number generator website, the studied patients were randomly allocated into 2 equal groups. This proper randomization justifies the lack of significant differences between the two groups concerning demographic characteristics, toxicological and clinical data, vital signs, routine laboratory investigations, and ECG findings at the time of admission. Randomization is an essential requirement of rigorously planned clinical trials. It minimizes all sources of bias, thereby valid results regarding the new medical intervention could be obtained (Jeffery et al., 2020).

In the present study, serum clozapine concentrations were measured on admission by HPLC to confirm the diagnosis of acute clozapine toxicity. It was positive in all clozapine intoxicated patients, with no significant association between serum clozapine concentrations and the severity of intoxication. Liquid chromatography is one of the specific and sensitive methods which can detect even minute amounts of the drugs (Silva Gracia et al., 2017). It is important to note that the role of measuring the blood clozapine concentration was to confirm the diagnosis. The severity of the intoxication appears to be unrelated to serum clozapine concentrations (Greenwood-Smith et al., 2003). The patients may have adverse reactions with a therapeutic dose of clozapine (Cadeddu et al., 2015).

The total amount of ILE taken by the patients in the intervention group ranged from 90 to $850 \mathrm{ml}$ with a median amount of $335 \mathrm{ml}$. This finding is in line with Finn et al. (2009) who reported successful treatment of a case of quetiapine overdose by using $500 \mathrm{ml}$ of ILE. On other hand, Hoegberg et al. (2016) systematically reviewed the effect of ILE on 73 case reports and one case series of local anesthetic drug toxicity and found that the total amount of administered ILE ranged from 9 to $2480 \mathrm{ml}$.
Regarding the outcome measures in the studied groups, no fatalities were recorded in the current study following antipsychotics overdose. This coincides with Meli et al. (2014) who recorded no fatalities among children poisoned by antipsychotics. Moreover, Abdalwahab and Youssof (2020) reported survival of all clozapine poisoned patients with no deaths. Absent fatalities reported in the current study might be due to absent fatal ventricular dysrhythmias in the studied patients.

In the present study, follow-up GCS assessments six and twelve hours later after admission revealed significantly quicker recovery of consciousness in patients administered ILE compared to their controls. The median GCS assessed at 6 hours was 15 in the intervention group compared to 10 in the control group. In addition, the intervention group's median GCS at 12 hours was 15 , while the control group's was 14 . This agrees with Finn et al (2009) who observed a rapid improvement in the level of consciousness immediately after ILE administration in a case of quetiapine overdose. As well, it has been reported that ILE could reverse altered consciousness levels in patients with local anesthetic CNS toxicity (Moshiri et al., 2014). A previous RCT investigated the effect of $10 \mathrm{cc} / \mathrm{kg}$ ILE $10 \%$ in the management of acute non-local anesthetic drug toxicity, they reported significant improvement of GCS 6 hours after admission in the intervention group compared to the control group (Taftachi et al., 2012).

Prolonged QTc interval is a fatal consequence reported in various antipsychotic drugs poisoning. It may lead to fatal arrhythmias including torsade de pointes and ventricular fibrillation (Chohan et al., 2015). The administration of ILE in this study was effective in the rapid control of the prolonged QTc interval and was accompanied by a decreased incidence of prolonged QTc interval at 12 hours after admission in comparison with the control patients. Additionally, the median QTc interval at 12 hours after admission was significantly longer in the patients of the control group compared to those in the intervention group ( $0.48 \mathrm{sec}$ versus $0.44 \mathrm{sec}$ respectively).

This result agrees with Hieger and Peters (2020) who investigated the effect of ILE therapy in quetiapine overdosed female patient. She presented with dropped blood pressure (78/35 mm $\mathrm{Hg}$ ), tachycardia (HR was $141 \mathrm{~b} / \mathrm{m}$ ), and ECG was significant for QT prolongation $(\mathrm{QTc}=0.558 \mathrm{sec})$ then lipid emulsion therapy $(20 \%)$ was initiated in the same dose of the current study. After ILE therapy, the QTc was improved to $0.44 \mathrm{sec}$ and the patient became vitally stable.

Furthermore, Bartos and Knudsen (2013) reported a case with antipsychotic overdose, manifested by GCS of 3, severe hypotension, and ECG abnormalities in the form of sinus tachycardia $(133 \mathrm{~b} / \mathrm{m})$, a widened QRS interval $(0.104 \mathrm{sec})$, and prolonged QTc interval (0.467 $\mathrm{sec})$. The cardiovascular collapse, in this case, was refractory to volume resuscitation and vasopressor treatment. Subsequently, ILE was given intravenously and within the first hour of its initiation, her circulation 
became stable. Recently, Thanacoody (2020) stated that ILE is recommended in severe antipsychotics overdose refractory to vasopressors treatment and it can be used in patients with cardiovascular collapse.

The current study provides evidence of ILE's role in the recovery of antipsychotic poisoned patients as it is recorded that it could shorten the prolonged QTc interval back to its normal value, Thus, decreasing the hospital stay period and the need for ICU admission and mechanical ventilation. This is supported by ElGharbawy and Ghonem (2018) who observed that there is a significant association between the prolonged QTc interval and the increased mortality rate, the need for ICU admission, and mechanical ventilation.

The most accepted mechanism of ILE's protective effect against intoxication by lipophilic drugs by general is the "lipid sink" theory. It suggests that lipophilic agents, like antipsychotic drugs, are redistributed from their site of action to a new inert compartment caused by the ILE itself in the vessels (Moshiri et al., 2014). Moreover, ILE provides highenergy essential fatty acids as well as polyunsaturated fatty acids that are essential for the brain's metabolism and the production of bioactive chemicals. Recently, Nie et al. (2020) reported that ILE may perform its CNS protective effects by preventing the increase in the blood brain barrier permeability.

In this study different types of antipsychotic drugs have been recruited. Despite this, it is worth mentioning that the absorption rate after oral ingestion as well as the bioavailability is approximately comparable. This might favor the feasibility of ILE adjuvant therapy in poisoning induced by different classes of antipsychotics (Demeter and Burns, 2016; Nasrallah and Tandon, 2017).

Together with the lipid sink theory; there are other mechanisms by which ILE induces a protective cardiovascular effect. Intravenous lipid emulsion provides fatty acid supply, induces reversal of mitochondrial dysfunction, provides inotropic effects and inhibition of nitric oxide release together with the reversal of sodium channel blockade in the cardiac cells that lead to controlling of QTc interval prolongation (Ok et al., 2018).

Regarding the need for intubation and/or ICU admission, this study showed that only $10 \%$ of all patients were candidates for endotracheal intubation and/or ICU admission. This result is consistent with Borg et al. (2016) who reported only $8 \%$ incidence of ICU admission among 157 antipsychotic poisoned patients. Furthermore, Abdalwahab and Youssof (2020) in their study at Poison Control Center-Ain shams university, reported only one case required mechanical ventilation out of 107 clozapine poisoned patients. The need for intubation and/or ICU admission was mainly for patients with chest complications rather than those with cardiovascular side effects as stated by El-Gharbawy and Ghonem (2018).

Another notable effect of ILE usage in this study was a significant reduction in the length of stay in the hospital. The median values of hospital stay in the control and intervention groups were 42 \& 18 hours respectively. This coincides with Arslan et al. (2013) who observed a rapid improvement in the patient's condition after ILE therapy in antipsychotics overdose. This may be explained by the observed role of the ILE in rapidly recovering consciousness and normalization of the prolonged QTc interval. This is supported by Mubarak et al. (2019) who reported a significant association between GCS and the duration of hospital stay. They concluded that low GCS is a predictor of prolonged hospital stay.

Concerning the safety of the used regimen of ILE in this study, clinical monitoring of the patients did not reveal any adverse effects of ILE. Moreover, a comparison of serum triglycerides levels, platelet count, and liver enzymes on admission time and at 12 hours later, during the follow-up of the interventional group, revealed no significant differences. These results were following Hieger and Peters (2020) who reported in their case report that serum triglycerides levels, liver enzymes, and $\mathrm{CBC}$ were within normal limits after ILE treatment.

Pancreatitis, lipoid pneumonia, acute lung injury, allergy, hypercoagulability, and fat embolism have been reported as theoretical side effects of ILE therapy (Arslan et al., 2013). Furthermore, fat overload syndrome characterized by fever, hepatosplenomegaly, jaundice, respiratory distress, and coagulopathy has also been reported (Hojsak and Kolaček, 2014) after rapid infusion of ILE. These complications are mainly related to the rapid infusion rate of high doses beyond the recommended doses. The current guidelines recommend a slow ILE infusion rate of less than 12 $\mathrm{ml} / \mathrm{kg}$ in 24 hours (Karcioglu, 2017). This could explain the absence of any of ILE adverse effects in this study as it was given to the patients by slow IV infusion.

\section{Limitations}

There are some limitations of this RCT including the small sample size, being an open-label, and a single-center study. Moreover, there was no availability for the follow-up of serum clozapine concentrations to show the mechanisms of ILE effects in this regard.

\section{Conclusion}

Intravenous lipid emulsion was an overall safe therapy if it was given within the recommended dose by slow IV infusion. Furthermore, it was effective in improving consciousness and the prolonged QTc and associated with a shorter duration of hospital stay in moderate to severe acute antipsychotic drug poisoning. Based on the successful therapeutic cardiovascular and neurological effects of ILE, this study could be considered as a preliminary clinical trial to register ILE as a specific antidote for antipsychotic overdosed patients.

\section{References}

Abdalwahab, W. A. \& Youssof, H. (2020): Characteristics and outcome of acute clozapine intoxicated patients with special consideration to its cardiac manifestations. The Egyptian Journal of 
Forensic Sciences and Applied Toxicology. 20(2), 73-84.

Adem, A., Madjid, N., Stiedl, O., Bonito-Oliva, A., Konradsson-Geuken, ̊., Holst, S., Fisone, G. \& Ögren, S. O. (2019): Atypical but not typical antipsychotic drugs ameliorate phencyclidineinduced emotional memory impairments in mice. European Neuropsychopharmacology. 29(5), 616-628.

Adeosun, I. I. (2016): Treatment persistence associated with typical versus atypical antipsychotics among out-patients with schizophrenia. Journal of Pharmaceutical Research International.10 (4), 1-8.

Anez-Bustillos, L., Dao, D. T., Baker, M. A., Fell, G. L., Puder, M. \& Gura, K. M. (2016): Intravenous fat emulsion formulations for the adult and pediatric patient: understanding the differences. Nutrition in Clinical Practice. 31(5), 596-609.

Arslan, E. D., Demir, A., Yilmaz, F., Kavalci, C., Karakilic, E. \& Çelikel, E. (2013): Treatment of quetiapine overdose with intravenous lipid emulsion. The Keio journal of medicine. 62(2), 5357.

Ayano, G. J. (2016): Dopamine: receptors, functions, synthesis, pathways, locations and mental disorders: review of literatures. Journal of Mental Disorders and Treatment. 2 (120), 2-6.

Barman, B., Bora, K. \& Nongpiur, A. (2018): Poisoning in elderly. Indian Journal of Medical Specialities. 9 (3), 113-117.

Bartos, M. \& Knudsen, K. (2013): Use of intravenous lipid emulsion in the resuscitation of a patient with cardiovascular collapse after a severe overdose of quetiapine. Clinical Toxicology. 51(6), 501-504.

Borg, L., Julkunen, A., Rørbæk Madsen, K., Strøm, T. \& Toft, P. (2016): Antidepressant or antipsychotic overdose in the intensive care unit-Identification of patients at risk. Basic \& clinical pharmacology \& toxicology. 119 (1), 110-114.

Cadeddu, G., Deidda, A., Stochino, M. E., Velluti, N., Burrai, C. \& Del Zompo, M. (2015): Clozapine toxicity due to a multiple drug interaction: a case report. Journal of medical case reports. 9 (1), 77-83.

Casson, C., Nguyen, V., Nayak, P., Channabasappa, N., Berris, K., Panczuk, J., Bhiladvala, C., Dasgupta, T. \& Piper, H. G. (2020): A comparison of Smoflipid® and Intralipid $\AA$ in the early management of infants with intestinal failure. Journal of Pediatric Surgery. 55 (1), 153-157.

Chohan, P. S., Mittal, R. \& Javed, A. (2015): Antipsychotic medication and QT prolongation. Pakistan journal of medical sciences. 31(5), 1269-1271.

Corponi, F., Fabbri, C., Boriani, G., Diemberger, I., Albani, D., Forloni, G. \& Serretti, A. (2019): Corrected QT interval prolongation in psychopharmacological treatment and its modulation by genetic variation. Neuropsychobiology. 77 (2), 6772.

Demeter, B.L. \& Burns, M. J. (2016): Antipsychotics. In: Critical care toxicology, Brent,
J., Burkhart, K., Dargan, P., Hatten, B., Megarbane, B. \& Palmer, R. (Eds), Springer, Cham, pp. 1-27.

Doig, G. S. \& Simpson, F. (2005): Randomization and allocation concealment: a practical guide for researchers. Journal of critical care. 20 (2), 187 191.

El-Gharbawy, D. \& Ghonem, M. (2018): ECG changes as a predictive tool of outcomes in antipsychotics poisoned patients. Ain Shams Journal of Forensic Medicine and Clinical Toxicology. 31(2), 51-61.

Finn, S. D. H., Uncles, D. R., Willers, J. \& Sable, N. (2009): Early treatment of a quetiapine and sertraline overdose with Intralipid®. Anaesthesia. 64(2),191-194.

Gibiino, S., Trappoli, A., Balzarro, B., Atti, A. R. \& De Ronchi, D (2015): Coma after quetiapine fumarate intentional overdose in a 71-year-old man: a case report. Drug safety-case reports. 2 (1), 1-7.

Gosselin, S., Hoegberg, L. C., Hoffman, R. S., Graudins, A., Stork, C. M., Thomas, S. H., Stellpflug, S. J., Hayes, B. D., Levine, M., Morris, M., Nesbitt-Miller, A., Turgeon, A. F., Bailey, B., Calello, D. P., Chuang, R., Bania, T. C., Mégarbane, B., Bhalla, A. \& Lavergne, V. (2016): Evidence-based recommendations on the use of intravenous lipid emulsion therapy in poisoning. Clinical Toxicology. 54 (10), 899-923.

Greenwood-Smith, C., Lubman, D. I. \& Castle, D. J. (2003): Serum clozapine levels: a review of their clinical utility. Journal of Psychopharmacology. 17(2), 234-238.

Gummin, D. D., Mowry, J. B., Spyker, D. A., Brooks, D. E., Beuhler, M. C., Rivers, L. J., Hashem, H.A. \& Ryan, M. L. (2019): 2018 Annual Report of the American Association of Poison Control Centers' National Poison Data System (NPDS): 36th Annual Report. Clinical toxicology. 57 (12), 1220-1413.

Hartman, M. \& Cheifetz, I. (2011): Pediatric emergencies and resuscitation. In: Nelson Textbook of Pediatrics, Kliegman, R., Stanton, B., Geme, J., Schor, N. \& Behrman, R. (Eds), $19^{\text {th }}$ edition, Ch. 62, Philadelphia: Elsevier Saunders, pp.279-295.

Hieger, M. A. \& Peters, N. E. (2020): Lipid emulsion therapy for quetiapine overdose. American Journal of Therapeutics. 27(5), e518-e519.

Hoegberg, L. C., Bania, T. C., Lavergne, V., Bailey, B., Turgeon, A. F., Thomas, S. H., Morris, M., MillerNesbitt, A., Mégarbane, B., Magder, S. \& Gosselin, S. (2016): Systematic review of the effect of intravenous lipid emulsion therapy for local anesthetic toxicity. Clinical Toxicology. 54(3), 167193.

Hoffmann, F., Schmalhofer, M., Lehner, M., Zimatschek, S., Grote, V. \& Reiter, K. (2016): Comparison of the AVPU scale and the pediatric GCS in prehospital setting. Prehospital emergency care. 20(4), 493-498.

Hojsak, I. \& Kolaček, S. (2014): Fat overload syndrome after the rapid infusion of SMOF lipid emulsion. Journal of Parenteral and Enteral Nutrition. 38(1),119-121. 
Jeffery, N. D., Olby, N. J., Moore, S. A. \& Canine Spinal Cord Injury Consortium (CANSORT-SCI) (2020): Clinical trial design-A review-with emphasis on acute intervertebral disc herniation. Frontiers in veterinary science. 7(2), 583-595.

Karakilic, E., Kaya, E., Erdem, A., Arslan, E. D., Durdu, T., Tulgar, S. \& Iscanli, D. (2017): The impact of intravenous lipid emulsion on lipophilicity in poisoned patients: A systematic review. Biomedical Research. 28(16), 7060-7069.

Karcioglu, O. (2017): Use of lipid emulsion therapy in local anaesthetic overdose. Saudi Medical Journal. 38(10), 985-993.

Krause, M., Zhu, Y., Huhn, M., Schneider-Thoma, J., Bighelli, I., Nikolakopoulou, A. \& Leucht, S. (2018): Antipsychotic drugs for patients with schizophrenia and predominant or prominent negative symptoms: a systematic review and metaanalysis. European archives of psychiatry and clinical neuroscience. 268 (7), 625-639.

Mazer-Amirshahi, M., Porter, R. \& Dewey, K. (2019): Prolonged QRS widening after aripiprazole overdose. Pediatric emergency care. 35(11), e209e212.

McPhie, M. L. \& Kirchhof, M. G. (2020): A systematic review of antipsychotic agents for primary delusional infestation. Journal of Dermatological Treatment. 13 (1),1-47.

Meli, M., Rauber-Lüthy, C., Hoffmann-Walbeck, P., Reinecke, H.J., Prasa, D., Stedtler, U., Färber, E., Genser, D., Kupferschmidt, H., Kullak-Ublick, G.A. \& Ceschi, A., (2014): Atypical antipsychotic poisoning in young children: a multicentre analysis of poisons centres data. European journal of pediatrics. 173(6), 743-750.

Minns, A. B. \& Clark, R. F. (2012): Toxicology and overdose of atypical antipsychotic. The Journal of emergency medicine. 43(5), 906-913.

Moshiri, M., Mohammadpour, A. H., Vahabzadeh, M., Etemad, L., Memar, B. \& Hosseinzadeh, H. (2014): Evaluating the effects and safety of intravenous lipid emulsion on haloperidol-induced neurotoxicity in rabbit. BioMed research international, 949262.

Mubarak, M., El Madah, E., El Gharbawy, D. \& Ashmawy, M. (2019): Assessment of acute antipsychotic poisoned cases admitted to Tanta University Poison Control Unit. Ain Shams Journal of Forensic Medicine and Clinical Toxicology. 33(2), 113-125.

Nagamine, T. (2008): Olanzapine-induced elevation of serum triglyceride levels in a normal weight patient with schizophrenia. Internal Medicine. 47(3), 181182.

Nasrallah, A. H. \& Tandon, R. (2017): Antipsychotics. In: The American psychiatric association publishing textbook of psychopharmacology, Schatzberg, A. F. \& Nemeroff, C. B. (Eds.), 5th edition, ch. 3, Arlington, American Psychiatric Association Publishing, pp. 603-623.

Nelson, L., Lewin, N., Howland, M. A., Hoffman, R., Goldfrank, L. \& Flomenbaum, N. (2011): Initial evaluation of the patient: Vital signs and toxic syndromes. In: Gold frank's toxicologic emergencies, Nelson, L., Lewin, N., Howland, M. A., Hoffman, R., Goldfrank, L. \& Flomenbaum, N. (Eds), $9^{\text {th }}$ edition, Ch. 3, New York, McGraw-Hill Professional, pp. 36-41.

Nie, H., Bai, Z., Li, Z., Yan, L. \& Chen, X. X. (2020): Intravenous lipid emulsion modifies synaptic transmission in hippocampal CA1 pyramidal neurons after bupivacaine-induced central nervous system toxicity. Journal neurochemistry. 154(2),144-157.

Oguz, F., Yildiz, I., Varkal, M. A., Hizli, Z., Toprak, S., Kaymakci, K., Saygili, S.K., Kilic, A. \& Unuvar, E. (2018): Axillary and tympanic temperature measurement in children and normal values for ages. Pediatric emergency care. 34(3), 169-173.

Ok, S. H., Hong, J. M., Lee, S. H. \& Sohn, J. T. (2018): Lipid emulsion for treating local anesthetic systemic toxicity. International journal of medical sciences.15(7), 713-722.

Persson, H. E., Sjöberg, G. K., Haines, J. A. \& de Garbino, J. P. (1998): Poisoning severity score. Grading of acute poisoning. Journal of Toxicology: Clinical Toxicology. 36(3), 205-213.

Purg, D., Markota, A., Grenc, D. \& Sinkovič, A. (2016): Low-dose intravenous lipid emulsion for the treatment of severe quetiapine and citalopram poisoning. Archives of Industrial Hygiene and Toxicology. 67(2), 164-166.

Raman, M., Almutairdi, A., Mulesa, L., Alberda, C., Beattie, C. \& Gramlich, L. (2017): Parenteral nutrition and lipids. Nutrients. 9 (4), 388-399.

Rasheed, E. A. M. A., Elmahdy, N., Shalaby, E., Karoube, H. S. \& Badawy, S. M. (2020): A study of pharmaceutical drugs poisoning cases admitted to the National Poisoning Center, Kasralainy Teaching Hospital in Cairo. Eurasian Journal of Emergency Medicine.19 (1), 5-10.

Silva Gracia, M., Köppl, A., Unholzer, S. \& Haen, E. (2017): Development and validation of an HPLCUV method for the simultaneous determination of the antipsychotics clozapine, olanzapine and quetiapine, several beta-blockers and their metabolites. Biomedical Chromatography. 31(10), e3968.

Spray, J.W. (2016): Review of intravenous lipid emulsion therapy. Journal of Infusion Nursing. 39 (6): 377-380.

Stassinos, G. \& Klein-Schwartz, W. (2017): Comparison of pediatric atypical antipsychotic exposures reported to US poison centers. Clinical toxicology. 55(1), 40-45.

Su, J. B., Yang, X. H., Zhang, X. L., Cai, H. L., Huang, H. Y., Zhao, L. H., Xu, F., Chen, T., Cheng, X.B., Wang, X.Q. and Lu, Y. (2017): The association of long-term glycaemic variability versus sustained chronic hyperglycaemia with heart rate-corrected QT interval in patients with type 2 diabetes. PloS one. 12(8), e0183055. 
Taftachi, F., Sanaei-Zadeh, H., Sepehrian, B. \& Zamani, N. (2012): Lipid emulsion improves Glasgow coma scale and decreases blood glucose level in the setting of acute non-local anesthetic drug poisoning-a randomized controlled trial. European Review for Medical and Pharmacological Sciences. 16 (Suppl 1), 38-42.

Tampakis, K., Vogiatzakis, N., Kontogiannis, C., Spartalis, M., Ntalianis, A., Spartalis, E., Siafaka, I., Iacovidou, N., Chalkias, A. \& Xanthos, T. (2020): Intravenous lipid emulsion as an antidote in clinical toxicology: a systematic review. European Review for Medical and Pharmacological Sciences. 24(12), 7138-7148.

Thanacoody, R. (2020): Antidepressant and antipsychotic poisoning. Medicine. 48(3), 194-196.

Wang, S., Che, T., Levit, A., Shoichet, B. K., Wacker, D. \& Roth, B. L. (2018): Structure of the D2 dopamine receptor bound to the atypical antipsychotic drug risperidone. Nature. 555 (7695), 269-273.

Yousefsani, B. S., Mohajeri, S. A., Moshiri, M., Jafarian, A. H. \& Hosseinzadeh, H. (2019): Effect of intravenous lipid emulsion on clozapine acute toxicity in rats. Journal of pharmacopuncture. 22, 147-153.

Zainuddin, Z. \& Zaini, S. (2018): QTc Prolongation and antipsychotic medications in psychiatric patients-A Review. Malaysian Journal of Psychiatry. 26(2), 70-92.

Zhang, Y., Qiu, S. \& Orlova, E. (2020): The systemic inflammatory response syndrome in acute antipsychotic poisoning. Journal of biochemical and molecular toxicology. 34(10), e22546.

\section{مستحلب الاهون الوريدي كعلاج مساعد فى التسمم الحاد بمضادات الذهان تجربة عشوائية منضبطة}

$$
\begin{aligned}
& \text { سارة ححسن بسيونى و منى سيد الجوهرى و فاطمة محمد الجزار و هبه ابراهيم لاشين' } \\
& \text { الملخص العربي }
\end{aligned}
$$

المقدمة: يعتبر التسمم بمضادات الذهان واحدا من أهم خمس مو اد المسبية للتسمم البشري. وقد وثقت تقارير لحالات مختلفة

$$
\text { الاستخدام الناجح لمستحلب الدهون الوريدي في علاج السمية الحادة لمضادات الذهان. }
$$

الهـف: تهدف هذه الدر اسة إلى تقييم أمان وفعالية مستحلب الدهون الوريدي كعلاج مساعد للتسمم الحاد بمضادات الذهان.

الطريقة المستخدمة في البحث: قد نم نوزيع · ؛ مريضاً مصابين بالتسمم الحاد بمضادات الذهان بدرجة سمية منوسطة إلى شديدة

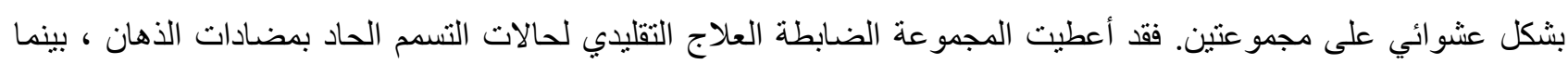
أعطيت مجموعة التدخل العلاج التقليدي في حالات التسمم الحاد بمضادات الذهان بالاضافة إلى مستحلب الدهون الوريدي. تم تسجيل التاريخ المرضي و البيانات السريرية لجميع المرضى وتم إجر اء رسم قلب وكذللك الفحوصات المخبرية الروتينية للمرضى بلى الخاضعين للار اسة. وقد تم تقييم مخرجات الأمان و الفعالية.

النتائج: أظهرت النتائج ان وسيط مستوى الوعي بمقياس جلاسجو والذي تم تقييمه عند 7 و با ساعة بعد دخول المستشفى كان

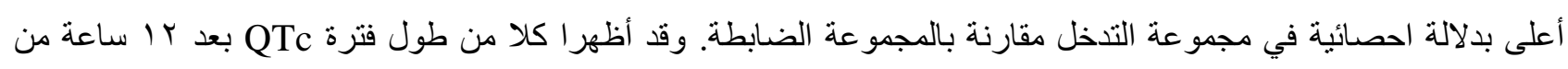
الدخول و فترة الإقامة في المستشفى قيما أقصر بفروق ذات دلائل إحصائية في مجموعة التدخل مقارنة بالمجموعة الضابطة. كما انه تبين عدم وجود فروق ذات دلائل احصائية عند مقارنة الدهون الثناثية في الدم و عدد الصفائح وإنزيمات الكبد عند الدخول وبعد r ا ساعة أثناء متابعة مجمو عة التدخل. الاستنتاج: لقد نم استنتاج أن مستحلب الدهون الوريدي هو علاج آمن وفعال للتسمم الحاد بمضادات الذهان. 